Економічні науки: збірник наукових прачь Луиького національного технічного університету. Серія "Регіональна економіка". Випуск 17 (67). Редкол.: відп. ред. к.е.н., професор І.В. Кривов'язюк. Луиьк: ІВВ Луцького НТУ, 2020. 348 с.

УДК 339.18:658.8

Волинчук Ю.В., к.е.н., доцент

Ковальчук Н.В., к.е.н., доцент

Кулик Ю.М., к.е.н., асистент

Луцький національний технічний університет

\title{
ЕЛЕКТРОННА ВЗАЄМОДІЯ В КЛЮЧОВИХ СЕКТОРАХ ЕЛЕКТРОННОЇ КОМЕРЦІї
}

Стаття присвячена дослідженню взаємозв'язків, що виникають між учасниками ринку електронної комерції. Проведено систематизацію усіх можливих форматів електронної взаємодії у вигляді матриці, в якій основні сектори розглядаються 3 позицій як споживачів, так і постачальників певних товарів, послуг або відповідного електронного контенту. Зокрема, виділено такі сектори як бізнес, споживачі, органи державної влади та місцевого самоврядування, наймані працівники. При цьому розглянуто особливості та безпосередні способи взаємодії для кожної із зазначених сторін в електронному форматі.

Ключові слова: електронна комерція, електронна взаємодія, інтернет, бізнес, споживачі, ринок, органи державної влади та місцевого самоврядування, торгівля, послуги. 


\section{Volynchuk Y., Kovalchuk N., Kulyk Y. \\ ELECTRONIC INTERACTION IN KEY SECTORS OF ELECTRONIC COMMERCE}

The scientific article concentrates attention on research of complex interaction, which arise up between all participants of market of electronic commerce on the modern stage. Electronic trade is examined as a basic element of electronic commerce which is confirmed the current legislation of Ukraine.

The conducted research allowed to systematize all possible formats of electronic co-operation as a difficult matrix. The basic sectors of matrix are examined with positions of both users and suppliers of certain products, commodities, services, or appropriate electronic content. In particular are selected such sectors as Business (B), Customers (C), Goverment (G) and Employee (E).

It is necessary to notice that mainly scientific researches touch such types of electronic commerce as Business-to-Business and Business-to-Consumer.

Development of artificial intelligence, innovative technologies of the complemented reality, possibility of remote access, to the arrays given, appearance of digital signature and new requirements and necessities through the pandemic of Covid-19 leads to nascence of modern forms of collaboration in format on-line, which remains out of eyeshot researches of this theme.

For example, to them it is possible to take public purchases through the system Prozorro in a sector Business-to-Government; realization of public projects on principle crowdfunding in a sector Customer-to-Business; various electronic registers are in a sector Government-to-Employees; grant of state electronic services is in a sector Business-to-Customer; forums and ratings of employers are from point of users in a sector Employees-to-Customer etc. The separate formats of cooperation touch directly adjusting of communication, retrieval of necessary data and receipt of feed-back, from users, that is powerful reserve of improvement of grant of services or improvement of informative content him users. Obviously, that the effective use of such reserves will have investigation the best satisfaction of consumer demand.

For every pair of intercommunications researched specific features, electronic platforms, possibilities of collaboration, perspective ways of strengthening of co-operation and others like that with accenting exactly on electronic subsoil of their origin and subsequent development.

Prospects of subsequent researches will take place in the sectors of noncommercial organizations (Noncommercial) and scientific structures (Science), what also in various forms builds mutual relations with business, government, citizens/users.

Key words: electronic commerce, electronic co-operation, internet, business, users, market, public and local self-government authorities, trade, services. 
Економічні науки: збірник наукових прачь Луиького національного технічного університету. Серія "Регіональна економіка". Випуск 17 (67). Редкол.: відп. ред. к.е.н., професор І.В. Кривов’язюк. Луцьк: ІВВ Луцького НТУ, 2020. 348 с.

\section{Волынчук Ю.В., Ковальчук Н.В., Кулык Ю.М. \\ ЭЛЕКТРОННОЕ ВЗАИМОДЕЙСТВИЕ В КЛЮЧЕВЫХ СЕКТОРАХ ЭЛЕКТРОННОЙ КОММЕРЦИИ}

Статья посвящена исследованию взаимосвязей, возникающих между участниками рынка электронной коммерции. Проведена систематизация всех возможных форматов электронного взаимодействия в виде матрицы, в которой основные сектора рассматриваются с позиций как потребителей, так и поставщиков определенных товаров, услуг или соответствующего электронного контента. В частности, выделены следующие сектора бизнес, потребители, органы власти и наемные работники. При этом рассмотрены особенности и непосредственные способы взаимодействия для каждой из указанных сторон в электронном формате.

Ключевые слова: электронная коммерция, электронное взаимодействие, интернет, бизнес, потребители, рынок, органы государственной власти и местного самоуправления, торговля, услуги.

\section{Постановка проблеми у загальному вигляді та їі} зв'язок 3 важливими науковими та практичними завданнями. Україна має сприятливі умови для росту сегменту ринку електронної комерції. Зокрема, за проведеним у липні 2020 року дослідженням ГО «Союз споживачів України», середні темпи зростання цього ринку в світі - 12-14\%, в Україні - приблизно 17\%. Якщо у світі оцінюють оборот е-commerce у 2020 році на суму близько \$4 трлн, то в Україні прогнозується $\$ 4$ млрд. Середньостатистичний покупець, який користується послугами онлайн-комерції, за рік витрачає \$500. При цьому $19 \%$ споживачів постійно, а $78 \%$ споживачів час від часу купують необхідні товари саме онлайн [1].

Зважаючи на виклики пандемії Covid-19, у березні 2020 року компанія Shop-Express відкрила для українських бізнесів безкоштовний доступ до створення та адміністрування на власній платформі онлайн-магазинів. За результатами цієї пропозиції, за 2,5 місяці на платформі було створено понад 1200 нових інтернет- магазинів. Вражає, що 92\% підприємців, які створили онлайн-магазин протягом дії даної пропозиції, раніше не займалися інтернет-продажами. Очікується, що індустрія електронної комерції стане найбільшим бенефіціаром 
Економічні науки: збірник наукових прачь Луиького національного технічного університету. Серія "Регіональна економіка". Випуск 17 (67). Редкол.: відп. ред. к.е.н., професор І.В. Кривов'язюк. Луиьк: ІВВ Луцького НТУ, 2020. 348 с.

пандемії коронавірусу. Водночас, 3 іншого боку, це призводитиме до закриття звичайних офлайнових точок продажу.

Варто підкреслити, що переважно наукові дослідження стосуються таких парних утворень в електронній комерції як В2B та В2С. Тоді як фактично, розвиток штучного інтелекту, інноваційних технологій доповненої реальності, можливості віддаленого доступу до масивів даних, поява цифрового підпису та й вимоги часу через пандемію Covid-19 призводять до виникнення новітніх форм онлайн співпраці, які залишаються поза увагою дослідницької спільноти.

Відповідно, необхідним $€$ проведення наукових досліджень в даному напрямку задля ефективного використання потенціалу усіх задіяних учасників відносин ринку електронної комерції та максимального задоволення зростаючого споживчого попиту.

Аналіз останніх досліджень, у яких започатковано вирішення проблеми. Згідно Закону України «Про електронну комерцію», електронна комерція - це відносини, спрямовані на отримання прибутку, що виникають під час вчинення правочинів щодо набуття, зміни або припинення цивільних прав та обов'язків, здійснені дистанційно 3 використанням інформаційно-телекомунікаційних систем, внаслідок чого в учасників таких відносин виникають права та обов'язки майнового характеру [2].

Водночас, цим же Законом України дається визначення електронної торгівлі як господарської діяльності у сфері електронної купівлі-продажу, реалізації товарів дистанційним способом покупцю шляхом вчинення електронних правочинів із використанням інформаційно-телекомунікаційних систем.

На нашу думку, варто використовувати термін «електронна комерція», адже зазначений термін $є$ широко вживаний у світі. Крім того, всі міжнародні документи в сфері електронної торгівлі англійською мовою застосовують термін electronic commerce. Тому в подальшому електронна торгівля розглядатиметься як основна складова частина електронної 
Економічні науки: збірник наукових прачь Луиького національного технічного університету. Серія "Регіональна економіка". Випуск 17 (67). Редкол.: відп. ред. к.е.н., професор І.В. Кривов'язюк. Луиьк: ІВВ Луцького НТУ, 2020. 348 с.

комерції, якій притаманні всі ознаки підприємницької діяльності 3 тим застереженням, що вона провадиться за допомогою Інтернету чи інших мереж.

Цілі статті полягають у дослідженні основних способів взаємодії учасників ринку електронної комерції та їх характерних особливостей.

Виклад основного матеріалу дослідження 3 повним обгрунтуванням отриманих наукових результатів. В науково-практичному середовищі нині широко використовуються категорії В2В та В2С для скороченого пояснення взаємодії між бізнесом (Business) та його клієнтами (Consumer). При цьому зазначимо, що спектр цих взаємозв'язків значно ширший, адже часто задіяними в електронних комунікаціях бізнесу також виявляються державні органи виконавчої влади (що узагальнюється словом Government або Administration) та найманими працівниками підприємства (співробітники, Employees).

Відповідно, в таблиці 1 коротко представимо формати електронної комунікації в ключових секторах електронної комерції з точки зору узгодження економічних інтересів задіяних сторін і розглянемо їх особливості:

- B2G (business-to-government) - взаємовідносини між підприємством та державою, тобто взаємовідносини між комерційними структурами (підприємства, установи, організації) та виконавчою владою 3 метою розвитку та підтримки бізнесу. Це ділові зв'язки комерційних структур 3 державними організаціями (зокрема, проведення публічних закупівель через мережу Internet як через систему Prozzoro).

Прикладами таких взаємовідносин можуть бути також інформаційні веб-сайти органів виконавчої влади, де подано широкий перелік законодавчих і нормативних документів, що регламентують підприємницьку діяльність. Цей термін широко застосовують у теоретичних працях, де йдеться про ділове адміністрування;В2B (business-to-business) - дослівний переклад означає «бізнес для бізнесу» або міжкорпоративний бізнес; комерційна взаємодія між виробниками, оптовими 
Економічні науки: збірник наукових пращь Луцького національного технічного університету. Серія "Регіональна економіка". Випуск 17 (67). Редкол.: відп. ред. к.е.н., професор І.В. Кривов’язюк. Луцьк: ІВВ Луцького НТУ, 2020. 348 с.

посередниками, оптовими клієнтами та іншими підприємствами щодо здійснення співробітництва, оптових закупівель, поставок товарів;

Таблиця 1

Формати електронної взаємодії в ключових секторах електронної комерції*

\begin{tabular}{|c|c|c|c|c|c|}
\hline & \multicolumn{4}{|c|}{ ПОСТАЧАЛЬНИК ПРОДУКТУ / КОНТЕНТУ / СЕРВІСУ } \\
\hline & & $\begin{array}{c}\text { Consumer / } \\
\text { citizen }\end{array}$ & Business & $\begin{array}{c}\text { Government / } \\
\text { Administration }\end{array}$ & Employee \\
\hline 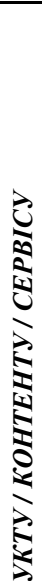 & 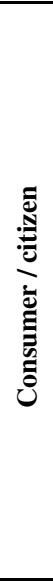 & \begin{tabular}{|c} 
С2С \\
Соціальні мережі. \\
Блоги. \\
Онлайн аукціони \\
(еВау). \\
Peer-to-peer \\
ресурси (напр., \\
файлообмінні \\
мережі). \\
Сайти приватних \\
оголошень (OLX) \\
та електронні \\
столи замовлень \\
(Uber, BlaBlaCar).
\end{tabular} & \begin{tabular}{|c} 
В2С \\
Транзакційні \\
ресурси (сайти \\
виробників, \\
електр. вітрини, \\
інтернет- \\
магазини, торг. \\
майданчики, \\
соціальні мережі). \\
Ресурси для побу- \\
дови взаємовід- \\
носин з брендом. \\
Побудовники \\
бренда (branders). \\
Медіа ресурси, \\
портали. \\
Сайти-агрегатори \\
цін (Ноline).
\end{tabular} & $\begin{array}{c}\mathbf{G 2 C} \\
\text { Сайти та портали } \\
\text { уряду з можливос- } \\
\text { тями надання } \\
\text { сервісних та } \\
\text { інформаційних } \\
\text { послуг та участі } \\
\text { громадян (прийом } \\
\text { електронних } \\
\text { декларацій, } \\
\text { довідки про } \\
\text { народження чи } \\
\text { місце реєстрації, } \\
\text { інформаційні } \\
\text { запити тощо) }\end{array}$ & \begin{tabular}{|c}
$\mathbf{E 2 C}$ \\
Форуми і \\
рейтинги робо- \\
тодавців очима \\
споживачів. \\
Побудова додат- \\
кових відносин з \\
клієнтами окреми- \\
ми співробіт- \\
никами компаній \\
(електронні листи \\
з бонусами за \\
повторні покупки, \\
супутній \\
додатковий сервіс \\
з прив'язкою до \\
співробітника).
\end{tabular} \\
\hline 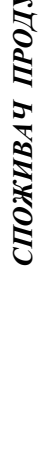 & 总 & $\begin{array}{c}\text { C2B } \\
\text { Форми зворотного } \\
\text { зв'язку. } \\
\text { Портали спільнот } \\
\text { (Tripadvisor). } \\
\\
\text { Crowdfunding } \\
\text { (майданчики для } \\
\text { громадського } \\
\text { фінансування } \\
\text { проектів). }\end{array}$ & \begin{tabular}{|c} 
B2В \\
Традиційні транз- \\
акційні ресурси, \\
електронні біржі. \\
Ресурси для \\
побудови взаємо- \\
відносин з \\
брендом. В2В \\
маркетплейси \\
Соціальні мережі, \\
орієнтовані на \\
бізнес-клієнтів \\
(напр., оптову \\
співпрацю).
\end{tabular} & $\begin{array}{c}\text { G2B } \\
\text { Сервісні та } \\
\text { транзакційні } \\
\text { сайти органів } \\
\text { виконавчої влади } \\
\text { для бізнес- } \\
\text { середовища } \\
\text { (тендери типу } \\
\text { Рrozorro, } \\
\text { автоматизація } \\
\text { податкових } \\
\text { виплат, видача } \\
\text { дозволів тощо). } \\
\text { Регулятори. } \\
\end{array}$ & $\begin{array}{c}\mathbf{E 2 B} \\
\text { Майданчики для } \\
\text { пошуку роботи і } \\
\text { розміщення } \\
\text { резюме }\end{array}$ \\
\hline
\end{tabular}


Економічні науки: збірник наукових прачь Луиького національного технічного університету. Серія "Регіональна економіка". Випуск 17 (67). Редкол.: відп. ред. к.е.н., професор І.В. Кривов’язюк. Луцьк: ІВВ Луцького НТУ, 2020. 348 с.

Продовження таблиці 1

\begin{tabular}{|c|c|c|c|c|}
\hline 范 & $\begin{array}{c}\mathbf{C 2 G} \\
\text { Зворотній зв'язок } \\
\text { (відгуки, скарги, } \\
\text { запити). } \\
\text { Електронні } \\
\text { петиції (напр., } \\
\text { petition.president.g } \\
\text { ov.ua). }\end{array}$ & $\begin{array}{c}\text { B2G } \\
\text { Системи } \\
\text { електронних } \\
\text { держзакупівель. } \\
\\
\text { Механізми } \\
\text { зворотного } \\
\text { зв'язку бізнесу та } \\
\text { недержавних } \\
\text { організацій з } \\
\text { урядом. }\end{array}$ & \begin{tabular}{|c} 
G2G \\
Електронний \\
внутрішній \\
документообіг \\
уряду (між \\
відомствами та \\
міністерствами). \\
Державні реєстри.
\end{tabular} & \begin{tabular}{|c}
$\mathbf{E 2 G}$ \\
Електронна \\
комунікація \\
співробітників \\
органів \\
виконавчої влади \\
та місцевого \\
самоврядування \\
(неофіційний \\
формат)
\end{tabular} \\
\hline 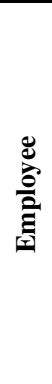 & - & \begin{tabular}{|c} 
B2E \\
Корпоративні \\
портали. \\
Онлайн \\
корпоративні \\
навчальні додатки \\
(вебінари тощо).
\end{tabular} & $\begin{array}{c}\mathbf{G 2 E} \\
\text { Надання } \\
\text { державних послуг } \\
\text { для державних } \\
\text { службовців. } \\
\text { Електронне } \\
\text { навчання } \\
\text { співробітників } \\
\text { органів } \\
\text { виконавчої влади } \\
\text { та місцевого } \\
\text { самоврядування }\end{array}$ & $\begin{array}{c}\mathbf{E 2 E} \\
\text { Внутрішні } \\
\text { корпоративні } \\
\text { мережі, форуми, } \\
\text { неформальні } \\
\text { канали зв'язку } \\
\text { (вайбер-групи, } \\
\text { телеграм-канали } \\
\text { тощо) }\end{array}$ \\
\hline
\end{tabular}

* удосконалено авторами на основі $[3 ; 4 ; 5 ; 6 ; 7]$

- B2C (business-to-consumer) - електронна роздрібна торгівля та інші аспекти взаємодії зі споживачем. У цьому випадку має місце комерційна взаємодія між електронним магазином та покупцем - безпосереднім споживачем товару. Найпоширенішим інструментом В2C $є$ інтернет-магазин, а також на даний час соціальні мережі (зокрема, Instagram);

- B2E (business-to-employee) - використання електронних ресурсів компанією для вирішення завдань управління персоналом та формування бренду роботодавця та інших корпоративні університети он-лайн, внутрішні корпоративні портали;

- $\mathrm{C} 2 \mathrm{C}$ (consumer-to-consumer) - взаємодія споживачів для обміну комерційною інформацією (щодо придбання того чи іншого товару чи про співпрацю 3 певною фірмою) або роздрібна торгівля між фізичними особами; у такому випадку веб-сайти є посередниками (торговельними майданчиками); 
Економічні науки: збірник наукових прачь Луиького національного технічного університету. Серія "Регіональна економіка". Випуск 17 (67). Редкол.: відп. ред. к.е.н., професор І.В. Кривов'язюк. Луиьк: ІВВ Луцького НТУ, 2020. 348 с.

- C2G (consumer-to-government, citizens-to-government) організація взаємодії між споживачами та державними структурами (особливо в соціальній та податковій сфері); системи соціального забезпечення (пенсії, соціальні виплати, пільги), комунального обслуговування, інформаційно-довідкова служба. Фактично, це сектор взаємодії між громадянами та органами влади в електронному уряді. Це взаємодія, пов'язана як із ініціативами громадян у сфері взаємин із органами влади, так і навпаки. До дій у цій сфері належать: податки та платежі, необхідні для отримання державних послуг; форми та інформація, що вимагаються органами влади для надання окремих державних послуг; штрафи та інші платежі; послуги, якими користуються громадяни в умовах надзвичайних ситуацій (пожежна служба, швидка медична допомога, допомога при крадіжках та інших злочинах); пропозиції та рекомендації стосовно відкритості та оптимізації процесу управлінської діяльності та участь громадян у процесі прийняття рішень;

- C2B (consumer-to-business) - цей формат комунікації дозволяє бізнесу отримати зворотний зв'язок від своїх споживачів або запустити збір коштів на фінансування i реалізацію громадських проектів за принципом crowdfunding;

- G2B (government-to-business) - сектор взаємодії між органами влади та суб'єктами підприємництва і включає продаж бізнесу надлишків-товарів, що належать державі, а також придбання державою у підприємців товарів і послуг. Іншими прикладами $є$ продовження дозволів і ліцензій, оформлення пільг для ведення бізнесу; сплата податків і виплату до фондів соцстрахування за співробітників; реєстрація нових компаній; надання інформації в статистичні органи; подача митних декларацій тощо;

- G2G (government-to-government) - форма електронної співпраці між державними установами для поліпшення взаємодії шляхом створення єдиного захищеного простору інформаційних ресурсів і документообігу між публічними органами влади у напрямах: оподаткування, митниці, фінансового менеджменту, збирання даних для статистики та 
Економічні науки: збірник наукових прачь Луиького національного технічного університету. Серія "Регіональна економіка". Випуск 17 (67). Редкол.: відп. ред. к.е.н., професор І.В. Кривов'язюк. Луиьк: ІВВ Луцького НТУ, 2020. 348 с.

перепису населення, виборів, охорони здоров'я, освіти і соціального забезпечення, соціального страхування та сільського господарства. Є напрями, пов'язані 3 діяльністю правоохоронних органів, національною безпекою та обороною, а також наукових установ;

- G2E (government-to-employee) - може стосуватися автоматизації процесів співпраці урядової системи 3 працівниками на місцях (державними службовцями чи службовцями органів місцевого самоврядування). Така взаємодія - ефективний засіб для забезпечення електронного навчання для співробітників, їх ефективної комунікації та обміну знаннями між ними; отримання співробітниками можливостей доступу до інформації стосовно політики компенсацій та виплати соціальних допомог, навчання чи можливості для підвищення професійної кваліфікації, доступ до законодавства тощо. Інші напрями у секторі G2E: е-платіжна відомість; е-навчання; е-реєстри; системи управління справами організації; системи управління персоналом;

- G2C (government-to-citizens) - сектор взаємодії між органами влади та громадянами в електронному уряді. Ініціаторами можуть бути обидві сторони. Мета цих ініціатив скоротити час на здійснення процедури надання органами влади управлінських послуг, а також спростити ці процеси за допомогою Інтернету. При цьому може здійснюватись така діяльність: інформування громадян про діяльність органів влади; надання державних електронних послуг, консультації онлайн; залучення громадян до прийняття рішень органами влади; громадянський контроль за діяльністю органів влади;

- E2C (employee-to-consumer) - на нашу думку, це стосується формування різноманітних рейтингів роботодавців для широкого загалу, що створені на основі опитувань їх працівників, а також може передбачатися побудова додаткових відносин $з$ клієнтами окремими співробітниками компаній;

- E2B (employee-to-business) - насамперед, це пропозиція робочої сили шляхом розміщення потенційними працівниками своїх резюме на спеціалізованих ресурсах для роботодавців; 
Економічні науки: збірник наукових прачь Луиького національного технічного університету. Серія "Регіональна економіка". Випуск 17 (67). Редкол.: відп. ред. к.е.н., професор І.В. Кривов'язюк. Луиьк: ІВВ Луцького НТУ, 2020. 348 с.

- E2G (employee-to-government) - в даному випадку розглядаємо електронну комунікацію співробітників органів виконавчої влади та місцевого самоврядування в неофіційному форматі;

- E2E (employee-to-employee) - організація взаємодії між співробітниками компанії за допомогою електронних ресурсів (форумів, закритих груп в соціальних мережах тощо).

За сучасних умов в просторі електронної взаємодії можна додатково виокремити дві великі та впливові групи - це сектор некомерційних організацій (Noncommercial) та науковий сектор (Science), який також у різноманітних формах будує взаємовідносини з бізнесом, урядом, громадянами/споживачами. Саме цей напрямок, а також питання посилення захисту особистих даних задіяних учасників можна вважати перспективними для проведення подальших досліджень.

Висновки. Таким чином, вивчення проблематики електронної взаємодії в ключових секторах електронної комерції та використання іiі можливостей розглядається потужним резервом задоволення споживчого попиту та нарощення обсягів реалізації продукції, товарів, послуг та якісного інформаційного контенту.

\section{Список бібліографічного опису}

1. Дослідження щодо ситуації на ринку електронної комерції в Україні. Громадська організація «Союз споживачів України». URL: https://www.consumers.support/?p=7149 (дата звернення: 01.10.2020).

2. Про електронну комерцію: Закон України від 16.07.2019 № 675VIII / Верховна Рада України. URL: https://zakon.rada.gov.ua/laws/show/675-19 (дата звернення: 01.10.2020).

3. Shaffey Dave, Ellis-Chdwick Fiona Digital marketing. Pearson Education Limited, 2012. 698 p.

4. Волинчук Ю.В., Камінська І.М. Формати електронної взаємодії в ключових секторах електронної комерції. Розвиток української держави в умовах активізації євроінтеграційних процесів: матеріали V Міжнародної науково-практичної конференції (19 березня 2020 р.). Київ, МАУП, 2020. C. $115-118$.

5. Електронне урядування та електронна демократія: навч. посіб. Частина 2: Електронне урядування: основи та стратегії реалізації. За ред. A.I. Семенченко, А.О. Серенок. К.: ФОП Москаленко О.М., 2017. 72 с. URL: https://onat.edu.ua/wp-content/uploads/2018/05/Part 002 Feb 2018.pdf _ (дата звернення: 01.10.2020). 
Економічні науки: збірник наукових прачь Луиького національного технічного університету. Серія "Регіональна економіка". Випуск 17 (67). Редкол.: відп. ред. к.е.н., професор І.В. Кривов’язюк. Луцьк: ІВВ Луцького НТУ, 2020. 348 с.

6. Кривов'язюк І.В., Кулик Ю.М. Проблеми застосування інформаційних технологій в управлінні логістичною системою підприємства. Актуальні проблеми економіки. 2013. № 12 (150). С. 254-262.

7. Писаренко Н.Л., Свдокимова 3.Р. Особливості функціонування та моделі бізнесу на ринку електронної комерції в Україні. Економічний вісник Начіонального технічного університету Украӥни «КПI». 2017. № 14. С. 348355.

\section{References}

1. Doslidzhennia shchodo sytuatsii na rynku elektronnoi komertsii v Ukraini. Hromadska orhanizatsiia «Soiuz spozhyvachiv Ukrainy». URL: https://www.consumers.support/?p=7149 (accessed 01.10.2020) [in Ukrainian].

2. Pro elektronnu komertsiiu: Zakon Ukrainy vid 16.07.2019 № 675-VIII / Verkhovna Rada Ukrainy. URL: https://zakon.rada.gov.ua/laws/show/675-19 (accessed 01.10.2020)_[in Ukrainian].

3. Shaffey Dave, Ellis-Chdwick Fiona Digital marketing. Pearson Education Limited, 2012. 698 p. [in English].

4. Volynchuk Yu.V., Kaminska I.M. Formaty elektronnoi vzaiemodii v kliuchovykh sektorakh elektronnoi komertsii. Rozvytok ukrainskoi derzhavy $\mathrm{v}$ umovakh aktyvizatsii yevrointehratsiinykh protsesiv: materialy V Mizhnarodnoi naukovo-praktychnoi konferentsii (19.03.2020). Kyiv, MAUP, 2020. P. 115-118. [in Ukrainian].

5. Elektronne uriaduvannia ta elektronna demokratiia: navch. posib. Chastyna 2: Elektronne uriaduvannia: osnovy ta stratehii realizatsii. Za red. A.I. Semenchenko, A.O. Serenok. K.: FOP Moskalenko O.M., 2017. 72 p. URL: https://onat.edu.ua/wp-content/uploads/2018/05/Part 002 Feb 2018.pdf (accessed 01.10.2020) [in Ukrainian].

6. Kryvovyazyuk I.V., Kulyk Yu.M. Problemy zastosuvannya informatsiynykh tekhnolohiy v upravlinni lohistychnoyu systemoyu pidpryyemstva. Aktual'ni problemy ekonomiky - Actual problems of economics, 2013, no. 12 (150), pp. 254-262 [in Ukrainian].

7. Pysarenko N.L., Yevdokymova Z.R. Osoblyvosti funktsionuvannia ta modeli biznesu na rynku elektronnoi komertsii v Ukraini. Ekonomichnyi visnyk Natsionalnoho tekhnichnoho universytetu Ukrainy «KPI» - Economic bulletin of National Technical University of Ukraine «Kyiv Polytechnic Institute». 2017. № 14. P. 348-355. [in Ukrainian]. 